\title{
Escrita e alfabetização ao longo da história da educação
}

no Brasil

\author{
Writing and literacy along the education history in Brazil \\ Juliana Ormastroni de Carvalho SANTOS $*^{1}$ \\ Pontifícia Universidade Católica de São Paulo (PUC-SP) \\ Faculdades Integradas Maria Imaculada (FIMI)
}

\begin{abstract}
RESUMO: Este artigo, fruto de uma pesquisa de Doutorado sobre o ensino de produção escrita, apresenta uma descrição sobre as metodologias e concepções referentes à apropriação da língua escrita para produção de textos ao longo da história da educação brasileira, do período jesuítico à atualidade. Este estudo justifica-se pela compreensão de que as diversas concepções de linguagem presentes nas propostas de ensino da língua no país caracterizam ou uma educação emancipadora ou tecnicista e descontextualizada. Será possível verificar que há um longo caminho percorrido no que se refere ao tema, desde o interesse restrito à leitura, passando pelos diferentes métodos de alfabetização, até chegar aos estudos de letramento, multiletramento e gêneros do discurso bastante discutidos atualmente.
\end{abstract}

PALAVRAS-CHAVE: Escrita. Alfabetização. Letramento. História da Educação no Brasil.

ABSTRACT: This article, the result of a doctoral research on the teaching of written production, presents a description about the methodologies and conceptions related to written language appropriacy for the text production along the history of Brazilian education, from the Jesuit period to the present day. This study is justified by the understanding that the different conceptions of language present in the language teaching proposals in the country characterize either an emancipatory or technicist and descontextualized. It will be possible to verify that there is a long way covered in the subject, from the restricted interest of reading, going through the different methods of literacy, up to getting to the studies of literacy, multiliteracies and speech genres quite discussed nowadays.

KEY WORDS: Writing. Literacy. Education History in Brazil

*Graduada em Letras e Pedagogia, Mestra em Educação e Doutora em Linguística Aplicada e Estudos da Linguagem pela PUC-SP. Atua na área de formação de professores e produção de textos. É professora das Faculdades Integradas Maria Imaculada (FIMI), em Mogi Guaçu, nos cursos de Letras e Pedagogia. Participa dos grupos de pesquisa da PUC-SP, em São Paulo. Email para contato: juocs@bol.com.br 


\section{Introdução}

Este artigo apresenta uma descrição bibliográfica sobre metodologias referentes à apropriação da língua escrita para produção de textos ao longo da história da educação brasileira. Este estudo justifica-se pela compreensão de que, nos modos como é proposto o processo ensino-aprendizagem da língua escrita, estão implícitas concepções de linguagem que podem caracterizar uma educação emancipadora ou tecnicista e descontextualizada. Será possível verificar que há um longo caminho percorrido no que se refere ao tema, desde o interesse restrito à leitura, passando pelos diferentes métodos de alfabetização, até chegar aos estudos de letramento, multiletramento e gêneros do discurso bastante discutidos atualmente.

A questão da escrita, sua apropriação e processos pelos quais a sua aprendizagem acontece é um tema vastamente estudado em diferentes áreas. No ambiente escolar e cotidiano, ecoam concepções decorrentes do senso comum, como ““escrita é inspiração'; [...] 'escrita é expressão do pensamento'; 'escrita é domínio de regras de língua'; 'escrita é trabalho' que requer a utilização de diversas estratégias da parte do produtor" (KOCH e ELIAS, 2011, p. 32). Tais crenças, embora bastante comuns na atualidade, necessitam ser superadas, principalmente se considerarmos os estudos hodiernos sobre a linguagem, numa visão de Linguística Aplicada enquanto "uma abordagem mutável e dinâmica para as questões de linguagem [...], como um modo de fazer e pensar sempre problematizador" (PENNYCOOK, 2006, p. 67).

Para garantir um caráter didático a este trabalho, foi promovida a seguinte organização das concepções de linguagem e ensino-aprendizagem: (a) a escrita nos séculos XVI, XVII e XVIII, com a educação jesuítica e a linguagem empregada para a dominação dos colonizadores; (b) os séculos XIX e meados do século XX marcados pelo ensino da gramática normativa; (c) a segunda metade do século $\mathrm{XX}$, com o predomínio do ensino tecnicista e o despontar de novas propostas para o ensinoaprendizagem da escrita; (d) os avanços observados entre 1985/ 90, e; (e) as questões de letramento e multiletramento.

Assinalo que tal divisão não é estanque nem bem delimitada e que muitas das concepções dos anos iniciais da escolarização brasileira ainda estão presentes nas 
práticas didáticas atuais. Também foram analisados os métodos de alfabetização de cada período, pois eles também revelam a concepção de linguagem da época.

\section{Séculos XVI, XVII e XVIII: educação jesuítica e a linguagem de dominação}

A história da educação formal no Brasil iniciou-se em 1549, a partir da colonização, de acordo com os interesses portugueses e com a ordem religiosa Companhia de Jesus. Os jesuítas seguiam o Ratio atque Institutio Studiorum Societatis Iesu, um detalhado manual com a indicação da responsabilidade, do desempenho, da subordinação e do relacionamento dos membros da hierarquia, dos professores e dos alunos.

Numa realidade muito distante das que até então tinham sido encontradas pelos jesuítas, os missionários, no Brasil, encontraram, nas brechas do Ratio Studiorum, a oportunidade de atuar de acordo com algumas necessidades locais. Os jesuítas introduziram o ensino profissional, uma vez que, para a construção das casas, igrejas, fazendas, colégios e vilas, era necessário mão-de-obra nos mais variados ofícios. Os padres aprendiam com os oficiais especializados do reino para ensinar aos colonos e aos índios de modo informal e prático.

Em relação à linguagem, segundo Paiva (1982), o conteúdo da catequese acontecia por meio de um código linguístico "inacessível” e "sem transposição", um código de comunicação

\footnotetext{
estabelecido a duras penas, ao papel de senha, uma senha especial- é verdade, que não só dava entrada à comunidade do dominante, mas obrigava mesmo à sua assimilação. Passou a não ter valor em si, e tornou-se um referente. $\mathrm{O}$ termo era o aportuguesamento, segundo os interesses predominantes (PAIVA, 1982, p. 53).
}

Aranha (1989) esclarece, ainda, que os padres aprenderam a língua tupi-guarani e elaboraram novos textos para serem usados na catequese, mas logo o bilinguismo chegou ao fim por exigência, pelos portugueses, do uso exclusivo da língua do colonizador. Aos índios couberam a "cristianização e a pacificação" (p. 121) e aos filhos dos colonos destinou-se o ensino do ler e escrever. Ainda segundo a autora, os 
jesuítas ensinavam latim e gramática para os brancos e mamelucos no curso de Humanidades que durava 2 anos e continha como leituras básicas autores antigos, cujas obras eram enviadas de Portugal. Como se pode observar, a linguagem era vista como instrumento de imposição e dominação dos indígenas e o ensino, conforme Gadotti (1995), destinava-se a formar as elites para exercer a hegemonia cultural e política.

Na segunda metade do século XVII, depois de duzentos e dez anos, os jesuítas foram expulsos do reino português e de suas colônias. Assim, em 1759, a educação jesuítica chegou ao fim com a expulsão executada por Marquês de Pombal, devido ao poder econômico e político adquirido pela Companhia de Jesus.

Pombal só retomou a reconstrução do ensino em 1772, quando propôs o sistema de aulas régias, que, conforme Monlevade (1997), funcionava da seguinte maneira:

quem soubesse mais que os outros e quisesse lecionar, poderia procurar um vereador da Câmara Municipal local que solicitaria do Rei a permissão para assumir a Aula pretendida, em nível primário ou secundário. Obtida a licença de Lisboa, o professor achava um local 'apropriado', [...], matriculava os alunos e recebia da Câmara um vencimento mensal (...) (MONLEVADE, 1997, p. 24).

O referido autor (op. cit.) esclarece que os poucos que passaram pela escola formaram a elite letrada, enquanto o povo era constituído pela a maioria analfabeta e trabalhadora.

\section{Séculos XIX e XX: educação elitista com foco no ensino da gramática normativa}

Em 1808, a família real mudou-se para a colônia, mas não há registro de mudanças e planejamento para uma educação sistemática e efetiva. Contrariamente, de acordo com Aranha (1989), "o descaso neste ponto é uma constante, e as poucas medidas tomadas são desastrosas" (p. 191). Continua ainda o sistema de aulas régias e a escola voltada às elites.

No período Imperial, entre 1822 e 1888, embora se registrem nessa época fatos importantes como a proclamação da Independência brasileira, em 1822, e a primeira constituição do país, em 1824, o caráter elitista e aristocrático é mantido no quadro educacional, como comprovam as palavras de Azevedo (1963): 


\begin{abstract}
Nessa sociedade, de economia baseada no latifúndio e na escravidão, e à qual, por isso, não interessava a educação popular, era para os ginásios e as escolas superiores que afluíam os rapazes do tempo com possibilidade de fazer os estudos. (...) Esse contraste entre a quase ausência de educação popular e o desenvolvimento de formação de elites tinha de forçosamente estabelecer, como estabeleceu, uma enorme desigualdade entre a cultura de classe dirigida, de nível extremamente baixo, e a da classe dirigente, elevando sobre uma grande massa de analfabetos. (AZEVEDO, 1963, p. 574)
\end{abstract}

Somente em 1838 a disciplina de língua portuguesa é introduzida oficialmente nos primeiros currículos para o ensino secundário, incluindo gramática, retórica e lógica ou dialética de maneira quase instrumental. Dessa época provem as crenças de que a escrita é um dom, portanto, não pode ser ensinada e de que, para escrever bem, basta ler bons modelos provenientes da literatura. Consequentemente, a avaliação centrava-se sobre aspectos gramaticais e ortográficos.

Segundo Clare (2002), o ensino de língua materna no século XIX relacionava-se à tradição de teoria e análise com raízes na filosofia grega, em que a linguagem era vista como expressão de pensamento. Koch e Elias (2011) trazem mais esclarecimentos sobre essa visão, afirmando que ela implica um entendimento de sujeito individual, que procura transpor sua representação mental para o papel e deseja que esta "seja 'captada' pelo leitor da maneira como foi mentalizada" (p. 33). Nessa concepção, o texto seria um produto lógico do pensamento e a escrita, atividade por meio da qual o sujeito expressa seu pensamento e cuja compreensão desconsidera os conhecimentos do leitor, o contexto de recepção e a interação.

No tocante a questões de alfabetização, de acordo com Mortatti (2000), o ensino da leitura se dava por meio do chamado método sintético, ou seja, o estudo fragmentado de letras, sílabas e valor sonoro das letras como ponto de partida para o entendimento das palavras. A escrita era vista independentemente da leitura e como uma habilidade motora, que demandava treino e cópia do formato da letra. Em 1876, o poeta João de Deus lançou, em Portugal, a Cartilha Maternal. Oliveira (1998) reconhece que esse material, voltado ao ensino da leitura, teve significativa repercussão no Brasil nesse período. Segundo a autora, a cartilha apresentava as partes das palavras em diferentes tonalidades de cinza e preto, partia do ensino das vogais, das consoantes, para depois passar às "invogais incertas- c, g, r, z, s, x, m, n. Finalmente, as invogais compostas certas th, rh, nh, lh, ph, a invogal incerta ch e o alfabeto maiúsculo" (OLIVEIRA, 
op.cit.). Mortatti (2000) afirma que a Cartilha Maternal ou arte da leitura, propunha a "complicação crescente" (p.64), enfatizava a aprendizagem da leitura, para o qual era necessário o desenvolvimento dos órgãos da voz e a harmonia entre o aparelho de fonação com a constituição cerebral.

De acordo com Mortatti (2000), o método usado até então era o de soletração, derivado do "brocado medieval "La letra com sangre entra"' (p. 42). Em seu estudo sobre a história da alfabetização no estado de São Paulo, a pesquisadora assinala nessa época a grande propagação das cartilhas e cita, dentre elas, a Cartilha Nacional, escrita por Hilário Ribeiro, provavelmente em 1880, e que em 1936 chega a $228^{a}$ edição. $\mathrm{Na}$ Cartilha Nacional (Novo Primeiro Livro), Hilário Ribeiro propõe o ensino simultâneo da leitura e da escrita em 32 lições e parte da concepção que a "leitura é a analyse da fala", que os alunos devem conhecer "os valores phonicos das letras, porque é com valor que há de ler e não com o nome dellas”.

É possível observar que a história da alfabetização no período de 1876 a 1890 é marcada pela disputa entre os partidários do novo método da palavração e os dos antigos métodos sintéticos (alfabético, fônico, silábico) ${ }^{2}$. Dessas informações, depreende-se que a alfabetização partia de uma visão de linguagem estruturalista, descontextualizada e distante de princípios comunicativos e interacionistas.

Nesse amargo cenário do início do século XX, em que o analfabetismo atingia $80 \%$ da população brasileira (ARANHA, 1989), registra-se o surgimento de intelectuais que debatem planos e reformas com a finalidade de superar o atraso educacional brasileiro. Nessa época, despontam importantes estudiosos que exercem grande repercussão na educação brasileira: Pestalozzi, Froebel, Dewey, Montessori, Herbart, entre outros. Surge o movimento da Escola Nova que, por meio de propostas baseadas em métodos centrados no aluno, com ênfase na sua formação integral, desencadeia uma série de reformas.

\footnotetext{
${ }^{2}$ De acordo com Mortatti (2010), os métodos de alfabetização classificam-se, basicamente, em dois tipos: o sintético (da parte para o todo), que incluía a soletração e a silabação, e o analítico (do todo para a parte). Esses métodos ainda se subdividem em: métodos sintéticos: alfabético, fônico, silábico; e métodos analíticos: da palavração, da sentenciação, da historieta, do conto.
} 
Assinala-se a Constituição de 1934 como a primeira a vincular uma percentagem dos recursos federais para a educação (MONLEVADE, 1997), além de criar o Conselho Nacional e Estadual de Educação. Em 1932, um documento redigido por Fernando Azevedo é publicado, o Manifesto dos pioneiros da educação nova, que defende a educação nacional, obrigatória, pública, leiga e gratuita como dever do Estado.

Quanto à alfabetização, Mortatti (2000) afirma que, de 1890 a meados dos anos de 1920, a escolarização inicial das crianças caracterizou-se pela disputa entre os defensores do novo método analítico (da palavração, da sentenciação, da historieta, do conto) e os dos antigos métodos sintéticos. De acordo com a pesquisadora, a partir do final de 1910, o termo "alfabetização" vai se consolidando, a leitura é "compreendida como instrumento de cultura, mediante o pensamento expresso por outrem" e, decorrente dela, a escrita é entendida como caligrafia e cópia, "e seu ensino envolve discussões respaldadas em teorias sobre os movimentos musculares requeridos e o tipo de letra manuscrita a ser utilizado: inclinada ou vertical" (MORTATTI, op.cit, p. 136). Enfatizava-se também a caligrafia, com cadernos elaborados a essa finalidade.

De acordo com essas informações, é possível afirmar que a educação, de forma geral, e aí também se incluem as questões de alfabetização e formação do leitor/autor, no período analisado, teve caráter elitista e dual. $\mathrm{O}$ ensino destinava-se a uma elite que valorizava a gramática normativa, baseada na norma padrão e a escola recebia alunos com domínio razoável do dialeto de prestígio, a norma padrão culta. Nos primeiros 50 anos do século XX coube à escola ensinar a gramática normativa, a leitura e a escrita por meio de textos literários.

Nessa educação voltada para a minoria da população, observa-se também a concepção de escrita segundo a qual, para escrever, o sujeito necessitava conhecer as regras gramaticais e ter um bom vocabulário. Essa visão de linguagem enquanto sistema pronto e fechado demanda um escritor que se aproprie de um sistema de regras gramaticais. Para Koch e Elias (2011), nessa concepção, o texto seria "simples produto de codificação realizada pelo escritor a ser decodificado pelo leitor, bastando para ambos, para tanto, o conhecimento do código utilizado" (p. 33). O código seria regido pelo princípio da transparência, ou seja, o que está escrito é o que deve ser entendido.

De acordo com Rajagopalan (2007), provém do positivismo a ideia de que o estudo da língua deveria ser realizado como um cientista que estuda seu objeto de 
análise, ou seja, o estudo da linguagem deveria se restringir à descrição da mesma. Ressaltamos que, conforme Iskandar e Leal (2002), o positivismo implica o estudo das tendências manifestadas pelos fenômenos observáveis, seguida por uma descrição, das relações entre os fenômenos e admite apenas o que é real, verdadeiro, inquestionável, objetividade essa que não se aplica a questões da linguagem dialética e dialógica.

Outra observação sobre a linguagem é o dualismo expresso nas concepções autor/leitor, codificar/decodificar e que também se reflete na concepção de aluno/professor e ensino/aprendizagem. De acordo com Behrens e Oliari (2007), a educação caracterizou-se pela tradicional visão newtoniano-cartesiana, segundo a qual os fenômenos só podem ser analisados e compreendidos se reduzidos às partes que o constituem, partindo do pressuposto básico da fragmentação e da visão dualista do universo. Assim, segundo Behrens (2005), o aluno é visto como um espectador, cujas tarefas limitam-se à cópia, à memorização e à reprodução dos conteúdos. A prática pedagógica tradicional desconsidera a experiência do aluno, visto como um ser subserviente, obediente e destituído de qualquer forma de expressão. O professor, visto como detentor do saber, tem como papel reproduzir e transmitir o conhecimento historicamente acumulado, seguindo currículos lineares e reducionistas, fragmentados em matérias. O ensino focaliza o resultado e não o processo desenvolvido.

\section{Segunda metade do século XX: do ensino tecnicista à busca de um novo ensino para a escrita}

Na década de 60, Clare (2002) assinala uma transformação na realidade da escola pública brasileira impulsionada pelo processo de democratização, consequência de um novo modelo econômico de desenvolvimento do capitalismo e de expansão industrial. A necessidade de desenvolvimento do capitalismo e da expansão industrial aumentou o acesso da população à escola, fato que não garantiu a permanência e a aprendizagem desse grande contingente. $\mathrm{O}$ que aconteceu, de fato, foi a mudança no público escolar, caracterizado, agora, pela heterogeneidade dialetal e a busca de um ensino utilitarista. De acordo com Rojo (2009), entre 1960-70, a política educacional priorizou a formação voltada à utilização de maquinarias ou à direção de processos de produção. 
A LDB 5.692/71 estabeleceu que a disciplina língua portuguesa passasse a ser chamada Comunicação e expressão no Ensino Fundamental I, Comunicação $e$ expressão em língua portuguesa no Ensino Fundamental II e Língua portuguesa e literatura brasileira no Ensino Médio. Monvelade (1997) registra que a democratização do acesso à escola na década de 60 provocou políticas públicas de ação social, como merenda e atendimento de saúde, mas a desqualificação da escola pública levou as classes médias e altas a procurarem a rede privada de ensino. O livro didático passou a ter grande peso como referenciais. Surgem os “"analfabetos funcionais': alguém que assina o nome, familiariza-se com letras e números, pega o 'sabor' da cultura letrada, mas não o hábito de ler e o saber científico" (MONVELADE, op. cit., 1997).

Diante da nova realidade linguística dos alunos que não provinham mais somente das classes privilegiadas e da busca de um ensino mais utilitário, a oralidade passou a ser privilegiada, em detrimento da gramática normativa. O ensino passou a configurar-se pela Teoria da Comunicação: “o aluno deve ser capaz de 'funcionar' como emissor e receptor de mensagens pela utilização de códigos verbais e não-verbais" (CLARE, 2002, s/p). O beletrismo diminuiu e os textos literários deram lugar aos gêneros da esfera jornalística. O ensino da língua, considerada instrumento de comunicação, passou a valorizar elementos de comunicação e funções da linguagem. No final da década de 70 , as propostas de redações em provas e exames vestibulares mostravam que se acreditava na crença de que escrever bem significava empregar técnicas de redação, como modelos pré-concebidos, e seguir o padrão culto da língua.

Segundo Smolka (2008), as propostas do ensino de Língua Portuguesa, entre 1960 e início de 1970, ainda desconsideravam as consequências da universalização do ensino, como a incorporação dos filhos das camadas menos favorecidas da população, davam continuidade à perspectiva gramatical e privilegiavam, assim, os alunos usuários de uma variedade linguística próxima da variedade padrão, cujas representações de mundo e de língua eram semelhantes às dos livros e textos didáticos. A autora esclarece que, nessas décadas, a "diferença" era vista como "carência cultural" ou "deficiência" (p. 16) que seria solucionada pela educação compensatória. Com o tempo, observou-se que tal educação não diminuiu os índices de evasão e repetência e a justificativa para isso passou da incapacidade da criança para a do professor, acusado de mal-formado e 
que, por isso, deveria compensar essa deficiência em cursos de treinamento e com a ajuda dos manuais para o professor. É nesse contexto que o livro didático ganhou o status de programa curricular e método e passou orientar a prática docente com atividades de leitura e escrita geralmente descontextualizadas e desprovidas de sentido. Informa Clare (2002) que, nas atividades de leitura, prevaleciam perguntas do livro didático, com respostas prontas no livro do professor, em atividades que não exigiam nenhuma reflexão. Smolka ( op. cit), baseada na Análise do Discurso para compreender o papel desempenhado pelo professor do ponto de vista da sociedade e do próprio docente, afirma que a esse é atribuída a tarefa de ensinar numa concepção linear, unilateral e estática, na qual o professor é um sujeito que se apodera (não se apropria) do conhecimento; e deve desempenhar a tarefa de dar o conhecimento à criança. Desse modo, por muito tempo, o professor monopolizou o espaço da sala de aula e a escola foi um lugar de papéis bem definidos e distintos: de um lado o professor que ensina e, de outro, o aluno que aprende.

Quanto à alfabetização, entre 1920 e final dos anos de 1970, segundo Mortatti (2000), o ensino inicial de leitura e escrita enfatizou elementos psicológicos, em detrimento dos pedagógicos e linguísticos, sob um processo de alfabetização de caráter funcional e instrumental a ser executado de maneira rápida, econômica e eficaz, com o objetivo de implantar uma educação renovada, "adequada ao projeto político de planificação e racionalização em todos os setores da sociedade brasileira" (p. 144). Destacam-se as disputas entre defensores dos antigos métodos de alfabetização e os dos novos testes $\mathrm{ABC}$ para verificação da maturidade necessária ao aprendizado da leitura e escrita, do que decorre a introdução dos novos métodos mistos ou analítico-sintético. Lourenço Filho lança a obra Testes $A B C$, em 1934, obra de propaganda ostensiva e formadora de opiniões, e que propõe a alfabetização como "instrumento de aquisição individual de cultura", envolvendo o aprendizado concomitante da leitura e da escrita, entendidas como "comportamentos que integram o conjunto de técnicas de adaptação" (MORTATTI, 2000, p. 146-147). Leitura e escrita eram vistos como processos dinâmicos, atividades que "se estruturam em comportamentos motores, em atividades de reação, por parte do aprendiz" (LOURENÇO FILHO, 1934, p. 48).

A partir de 1930, grande número e variedade de cartilhas passaram a ser publicadas, inclusive para a alfabetização de adultos. Mortatti (2000) explicita que os 
títulos das cartilhas revelam não mais a preocupação com o método, mas sim com o caráter lúdico da alfabetização e buscavam motivar o interesse do aprendiz. Entre 1950 e 1960, as primeiras edições das cartilhas Caminho Suave e Sodré são lançadas, respeitando a técnica dos métodos mistos. Na apresentação de Caminho Suave, com mais de 40 milhões de exemplares vendidos e distribuidores em 14 estados brasileiros, a autora, Branca Alves de Lima, afirma que emprega a "Alfabetização pela Imagem", baseada no método analítico-sintético e propõe o ensino-aprendizagem da leitura e escrita calcada nas tendências pedagógicas derivadas da Escola Nova, além da experiência pessoal.

Colares e Souza Colares (2003) assinalam que, por volta de 1961 a 1970, a alfabetização da população adulta ficou sob a responsabilidade do Movimento de Educação de Base (MEB), por meio de aulas radiofônicas. Em 1967, o governo federal criou o Movimento Brasileiro de Alfabetização (MOBRAL), a fim de propiciar ao governo as bases eleitorais, uma vez que saber escrever o nome era condição legal para que o sujeito fosse considerado um cidadão. O MOBRAL também apresentava um interesse econômico: uma pessoa alfabetizada era vista como potencial de consumo de materiais ligados à leitura e à escrita e também de produtividade, pois se torna mais capacitada. No entanto, apenas $15 \%$ dos alunos chegavam ao fim do curso de alfabetização.

O período de 80 é marcado por propostas curriculares inovadoras, à medida que se redemocratizava o país, entretanto, na prática, os professores apoiavam-se cada vez mais nos livros didáticos como recurso pedagógico. Para Rojo (2009), tais reflexões fizeram que o ensino da língua, entre 1970 a 1990, tornasse-se centrado em procedimentos. Datam dessa época muitas pesquisas de procedimentos cognitivos de leitura e produção de textos, estudos que apresentam como "mecanismos da escrita a geração de ideias, o planejamento e a organização das ideias, a produção propriamente dita (a escrita do texto) que se acompanha de mecanismos de editoração e de revisão, a revisão final" (ROJO, op.cit., p.88, itálicos da autora). Na prática, as práticas de produção de texto revelam a influência das teorias cognitivistas de produção, da linguística textual, cujos termos como coesão, coerência e intertexto tornam-se comuns nas escolas, e o texto era, na maioria das vezes, usado meramente como suporte para análises gramaticais. 
Nas discussões sobre alfabetização, de acordo com Mortatti (2000), o período entre meados de 1980 a 1994 é marcado pelas disputas entre os defensores da nova perspectiva construtivista e os dos antigos testes de maturidade e dos antigos métodos de alfabetização.

Clare (2002) refere-se à segunda metade da década de 80 como um "período de mudança", no qual despontam nomes como Carlos Franchi, Sírio Possenti, Luiz Carlos Travaglia, João Wanderley Geraldi, Luiz Percival Leme Britto, Rodolfo Ilari, Magda Soares com teses e dissertações que propõem alternativas para o ensino de língua portuguesa e, consequentemente, da escrita.

\section{1985/ 90: um salto qualitativo nas questões de escrita}

No início da década de 80, a difusão da pesquisa de Emília Ferreiro e Ana Teberosky no México sobre a aquisição da linguagem escrita chega ao Brasil e provoca novas reflexões sobre a alfabetização baseada, até então, na decodificação, na repetição e na reprodução (SMOLKA, 2008). Os trabalhos desenvolvidos, nessa época, nas áreas de linguística e psicolinguística, distanciaram-se da concepção normativa da língua e possibilitaram avanços consideráveis na área de educação e, principalmente, no tocante à aquisição da escrita quanto à ressignificação da noção de erro, à admissão das variedades linguísticas discentes, à valorização das hipóteses linguísticas elaboradas pelos alunos e ao trabalho com textos reais (Parâmetros Curriculares Nacionais: terceiro e quarto ciclos do ensino fundamental: língua portuguesa, 1998). A contribuição dessas pesquisas reside na percepção de que o trabalho com escrita na sala de aula deve considerar a realidade e os interesses do educando, as funções da escrita em todas as suas possibilidades para que o aluno encontre sentido nas atividades lecto-escritas.

É nas décadas de 80 e início dos anos 90 também que são publicadas, no Brasil, obras que exercem grande influência sobre a formação de professores e o ensino de língua portuguesa. Os livros "O texto na sala de aula", "Portos de Passagem", ambos de Wanderley Geraldi (1984/2001, 1991/2013), “E as crianças eram difíceis... a redação na escola", de Eglê Franchi (1984) e "Questões de Linguagem", organizado por Maria Helena Martins (1991), questionam antigas práticas e discutem a produção escrita na escola sob uma vertente comunicativa da linguagem e que leva em consideração as 
situações enunciativas. Exemplos disso podem ser observados nas obras de Geraldi (1984/2001, 1991/2013). Em “O texto na sala de aula" os autores descrevem algumas práticas de leitura e escrita comuns até então e começam a questioná-las. Por meio das discussões de Leite (2001), é possível vislumbrar como era nessa época o ensino da língua no ciclo II do Ensino Fundamental: um conjunto de regras gramaticais, com vistas à produção correta do enunciado, numa escola em que os alunos não leem ou escrevem livremente, mas o fazem para preencher fichas de leitura ou produzem redações seguindo determinados moldes. Em "Portos de passagem", Geraldi (1991/ 2013) defende interação verbal como o lugar da produção da linguagem e dos sujeitos que, neste processo, constituem-se pela linguagem, numa concepção de que a língua não está pronta, de que os sujeitos se constituem quando interagem com os outros e de que as interações se dão em um contexto social e histórico. A obra propõe a produção de textos orais e escritos como ponto de partida para o processo de ensino-aprendizagem e coloca que, para produzir um texto, é preciso que haja um locutor que tenha o que dizer, uma razão para isso, um interlocutor e estratégias para escrever, como seduzir o leitor ou fazer uma denúncia. Os textos para leitura, até então empregada como modelo a ser imitado ou material para verificação de perguntas ou de itens gramaticais, são propostos a partir de uma visão dialógica, em que "o movimento entre produção e leitura é para nós um movimento que vem da produção para a leitura e desta retorna à produção" (p. 188).

Em meados da década de 90, novas propostas para o trabalho com leitura e produção de texto são apresentadas em documentos oficiais, como os Parâmetros Curriculares Nacionais de Língua Portuguesa (1998). Os Parâmetros trazem propostas inovadoras quanto ao uso da linguagem, com um enfoque no uso comunicativo da fala, da escuta, da leitura e da escrita. De acordo com essa proposta, o domínio da língua relaciona-se intimamente com a possibilidade de participação social, visto que constitui meio de o sujeito ter acesso a informações, expressar e defender pontos de vista e construir concepções e conhecimentos. A leitura deixa de ser vista como exercício de decodificação. As práticas de leitura contidas no referido documento propõem essa atividade como um processo no qual o leitor exerce um trabalho ativo de construção do significado do texto, a partir dos seus objetivos, do seu conhecimento sobre o assunto, sobre o autor e sobre a língua. É uma tarefa que implica também a compreensão do que 
é lido e dos elementos implícitos ao texto, a percepção dos vários sentidos que podem ser atribuídos a um texto e a relação com as demais leituras feitas pelo sujeito.

A aprendizagem da escrita, por sua vez, distancia-se da codificação de sons e letras e aproxima-se da compreensão dos aspectos notacionais, ou seja, do entendimento do sistema de escrita da língua, e dos aspectos discursivos, entendidos como aqueles que se referem ao funcionamento da linguagem que se usa para escrever. As propostas de práticas de produção textual desse documento partem da premissa de que a escrita envolve a coordenação entre o que se pretende dizer e a quem se destina o texto, possibilitando a "aproximação máxima entre a intenção de dizer, o que efetivamente se escreve e a interpretação de quem lê" (Parâmetros curriculares nacionais: terceiro e quarto ciclos do ensino fundamental: língua portuguesa, 1998, p. 66).

As teses sobre práticas de ensino da língua da década de 80 passam a ser admitidas por órgãos públicos oficiais, fato que dá origem a novas propostas em currículos municipais e estaduais e em cursos de formação de professores. Atualmente, é consensual quanto às atividades de linguagem:

\footnotetext{
- a razão de ser das propostas de leitura e escuta é a compreensão ativa e não a decodificação e o silêncio;

- $\quad$ a razão de ser das propostas de uso da fala e da escrita é a interlocução efetiva, e não a produção de textos para serem objetos de correção;

- as situações didáticas têm como objetivo levar os alunos a pensar sobre a linguagem para poder compreendê-la e utilizá-la apropriadamente às situações e aos propósitos definidos. (Parâmetros curriculares nacionais: terceiro e quarto ciclos do ensino fundamental: língua portuguesa, 1998, p. 19).
}

Além da maior preocupação no desenvolvimento de situações de aprendizagem que fizessem sentido e estivessem situadas numa instância comunicativa, duas outras questões iniciadas nesse período são relevantes para pensarmos a produção escrita: o surgimento, a difusão e os debates sobre o conceito de letramento e a consideração dos gêneros do discurso no ensino de Língua Portuguesa. A importância das discussões relativas ao letramento recai sobre a necessidade de desenvolvimento de um processo que vai além das habilidades de ler e escrever, mas considera também o uso social dessas práticas. Pensar o ensino por meio dos gêneros do discurso, por sua vez, traz uma possibilidade mais ampla e completa de reconhecimento e produção dos enunciados. 
Justificada a importância de ambos, passemos a uma análise mais detalhada sobre letramento.

\section{Letramento e multiletramento}

Esta seção objetiva definir letramento, conceito que engloba a leitura e a escrita nos contextos da "vida que se vive" (MARX,1844/2004). Tratará também de registrar como os novos estudos sobre o letramento, em vista das mudanças motivadas pelas tecnologias da informação e da comunicação na sociedade contemporânea, desdobraram-se ao que foi cunhado como multiletramentos ou letramentos digitais.

De acordo com Soares (2004), a partir de 1980, diante da necessidade de reconhecer e nomear práticas sociais de leitura e de escrita que iam além da aprendizagem do ler e do escrever, ou seja, da aquisição do sistema de escrita, o termo letramento começa a ser foco de estudo e aprofundamento em vários países, como França, Estados unidos, Inglaterra e Brasil. Conforme Soares (1998/2012) e Magalhães (2012), o vocábulo foi introduzido no Brasil no livro No mundo da escrita: uma perspectiva psicolinguística, de Mary Kato, em 1986, oriundo da necessidade de um termo para se referir às pessoas que, além de saberem ler e escrever, faziam uso dessas habilidades na sociedade. Soares (2004) e Magalhães (op.cit.) assinalam ainda que, inicialmente, no Brasil, os conceitos de alfabetização e letramento não raro eram confundidos como sinônimos, embora a produção acadêmica tenha se esforçado em estabelecer e esclarecer a diferença entre os dois e, desde a década de 90, registram-se nessa área muitos estudos e obras. Dentre elas, Letramento: um tema em três gêneros, lançado em 1998 por Magda Soares, esclarece que alfabetização é "a ação de ensinar /aprender a ler e a escrever", enquanto letramento é o "estado ou condição de quem não apenas sabe ler e escrever, mas cultiva e exerce as práticas sociais que usam a escrita" (SOARES, op.cit, p.47). Em outras palavras, o letramento inclui, além da aquisição do ler e do escrever, a inserção do sujeito nas práticas sociais de leitura e escrita.

Reforçando essa distinção, Soares (2012) estabelece uma diferença entre a pessoa alfabetizada e a letrada: a primeira aprendeu a ler e a escrever, a segunda, envolve-se nas práticas sociais de leitura e escrita, ou seja, vive na condição ou estado de quem lê, escreve e pratica a leitura e a escrita. Em suas considerações, a autora 
coloca a necessidade de que haja condições para o letramento, dentre elas, que a escolarização seja real e efetiva a toda a população. Rojo (2009) também assinala a importância da escola em promover práticas nas quais o educando tenha contato com espaços de cultura pouco conhecidos por ele, como museus, exposições, teatros e rever suas práticas de letramento, consideradas elitizadas e insuficientes para grande parte da população.

Em contribuição à construção do conceito de letramento, alguns autores (MAGALHÃES, 2012; STREET, 1993; ROJO, 2009) estabelecem diferenças entre as concepções de Letramento Autônomo e o Letramento Ideológico. Para o Modelo Autônomo de Letramento existe uma relação entre escrita e desenvolvimento de habilidades cognitivas. Seguindo o pressuposto da autonomia, o sujeito pode "considerar-se capaz ou incapaz de escrever simplesmente com base no (des)conhecimento da gramática da língua (...)" (MAGALHÃES, op.cit.). Para Street (1993), nesse enfoque, o letramento é considerado em termos técnicos e independentemente do contexto social. Sobre esse enfoque, Rojo (2009) explica que seriam o contato escolar com a leitura e a escrita e a natureza da escrita que levariam o aluno a aprender habilidades gradualmente e que o levaria a estágios universais de desenvolvimento.

No enfoque ideológico proposto por Street (1995), a leitura e a escrita são práticas marcadas por relações de poder e por ideologias, sendo o letramento relacionado ao contexto social. Assim, o modelo de letramento ideológico considera questões relacionadas à cultura do indivíduo, as variedades de como a escrita é representada na sociedade e aborda as práticas discursivas.

Como se observa, o significado de letramento apresenta variações ao longo do tempo, em diferentes culturas e até mesmo em uma mesma cultura. Assim sendo, acompanhando essas transformações, assiste-se hoje a um novo tipo de letramento, emergente da sociedade contemporânea, e que amplia o conceito de letramento para dar conta da diversidade visual, verbal, sonora dos textos atuais. Rojo (2012), com base nos estudos do Grupo de Nova Londres (doravante, GNL), coloca a necessidade encontrada pelo grupo de a escola estar atenta aos novos letramentos caracterizados pela presença das recentes tecnologias da informação e da comunicação e à variedade de culturas presentes nas salas de aula. O GNL também apontava para novas formas de letramento, 
de caráter multimodal, multissemiótico e multicultural, fenômeno cunhado de multiletramentos. Rojo (op. cit. e 2009) acrescenta também as hipermídias a esse fenômeno e explica ainda que o conceito de multiletramento apresenta dois tipos importantes de multiplicidade: a de culturas e a semiótica. A multiplicidade de culturas refere-se à variedade de textos híbridos de letramentos locais ou vernaculares e, portanto, pouco valorizados, e de letramentos dominantes, de diferentes campos, que resulta numa hibridização baseada mais no diálogo (possibilitado pela navegação na web) entre os interpretantes do que na propriedade. A multiplicidade de semioses diz respeito às linguagens nos textos em circulação, nos quais as cores, imagens, diagramação produzem os significados dos textos contemporâneos. Segundo a pesquisadora, os letramentos

tornam-se multiletramentos: são necessárias novas ferramentas _ além da escrita manual (papel, pena, lápis, caneta, giz e lousa) e impressa (tipografia, imprensa) _ de áudio, vídeo, tratamento de imagem, edição e diagramação. São requeridas novas práticas:

(a) de produção, nessas e em outras, cada vez mais nova, ferramentas;

(b) de análise crítica como receptor (ROJO, 2012, p. 21, grifo da autora).

Para Lorenzi e Pádua (2012), os multiletramentos envolvem a diversidade cultural da produção e circulação de textos ou na diversidade da linguagem porque "levam em conta a multimodalidade (linguística, visual, gestual, espacial e de áudio) e a multiplicidade de significações e contextos/culturas” (p. 36). Teixeira e Moura (2012) complementam essa consideração quando afirmam que o prefixo "multi" refere-se não só à multiplicidade de linguagens, semioses e mídias envolvidas na significação dos textos multimodais, mas também envolve a pluralidade e a diversidade cultural dos autores e leitores que contribuem para a construção da significação.

A necessidade de reconhecimento e do ensino-aprendizagem de língua portuguesa com base nessa multiplicidade de linguagem também é endossada pela Base Nacional Comum (2017) (doravante, BNCC), que também reconhece os letramentos múltiplos e aponta a relevância em do desenvolvimento do ensino com base na exploração das variadas mídias e semioses dos textos.

\section{Considerações finais}


Este artigo percorreu pela periodicidade do ensino da língua portuguesa no Brasil de modo a levantar a percepção das concepções que embasam metodologias e práticas.

Nesse caminhar histórico, foi possível verificar que a linguagem é um instrumento de poder e que serve a interesses ideológicos. Observa-se, ainda, uma guinada significativa nas propostas de ensino da língua, mais especificamente quando se supera a concepção estruturalista de língua e o contexto imediato e histórico, o objetivo e os sujeitos das práticas discursivas passam a ser ressaltados. Outros avanços podem ser citados, como as orientações para que o ensino parta do texto como unidade de trabalho e da abordagem enunciativa-discursiva da linguagem. Ou a preocupação com a implementação das Tecnologias Digitais da Informação e Comunicação (doravante, TDIC) nas práticas de linguagem desenvolvidas em sala de aula, preconizadas pela BNCC (2017), com o intuito de ampliar as experiências de letramentos discentes e de colocá-los não só como consumidores da mídia, mas também produtores e críticos.

Por fim, registra-se que um longo caminho ainda há de ser percorrido: aquele da formação dos professores, da mudança de concepções, da implementação de políticas públicas que instrumentalizem as escolas com as TDIC, da valorização docente e tantos outros.

\section{REFERÊNCIAS}

ARANHA, M. L. A.. História da educação. 2.ed. São Paulo: Moderna, 1989.

AZEVEDO, F. de. A cultura brasileira: introdução ao estudo da cultura no Brasil. 4.ed. ver. Ed. ampl. Brasília, Editora UnB, 1963.

BRASIL. Ministério da Educação e do Desporto. Secretaria da Educação. Parâmetros curriculares nacionais: terceiro e quarto ciclos do ensino fundamental: língua portuguesa. Brasília: MEC/ SEF, 1998. Disponível em: < http://portal.mec.gov.br/seb/arquivos/pdf/portugues.pdf> Acesso em 09 ago. 2012.

Base Nacional Comum Curricular: Educação Infantil e Ensino Fundamental. Brasília: MEC/Secretaria de Educação Básica, 2017.

BEHRENS, M. O paradigma emergente e a prática pedagógica. Petrópolis: Vozes, 2005 . 
BEHRENS, M. e OLIARI, A. L. T. A evolução dos paradigmas na educação: do pensamento científico tradicional à complexidade. Revista Diálogo Educacional, Curitiba, v. 7, n. 22, p. 53-66, set./dez. 2007

CLARE, N. A. V. 50 anos de ensino de LP (1950-2000). Cadernos de Cnlf Ano VI, Rio de Janeiro, v. 01, p. 43, 2002.

COLARES, A. A.; SOUZA COLARES, M. L. I. Do autoritarismo repressivo à construção da democracia participativa: história e gestão educacional. Campinas: Autores Associados, 2003.

GADOTTI, M. História das ideias pedagógicas. São Paulo: Ática, 1995.

GERALDI, J. W. Unidades básicas do ensino de português. In: GERALDI, J. W. (org.). O texto na sala de aula. São Paulo: Ática, 2001, p. 59-81.

GERALDI, J. W. Portos de passagem. 5.ed. São Paulo: Martins Fontes, 2013.

ISKANDAR, J. I., LEAL, M. R. Sobre Positivismo e Educação. Revista Diálogo Educacional, Curitiba, v. 3, n.7, p. 89-94, set./dez. 2002. Disponível em $<$ < http://www.redalyc.org/pdf/1891/189118078007.pdf. $>>$. Acesso em 13 de janeiro de 2014.

KOCH, I. V. ELIAS, V. M. Ler e compreender: os sentidos do texto. 3 ed. São Paulo: Contexto, 2011.

LEITE, L. C. de M. Gramática e literatura: desencontros e esperanças. In: GERALDI, J. W. (org.). O texto na sala de aula. São Paulo: Ática, 2001, p. 17-25.

LORENZI, G. C. C. E PÁDUA, T. W. de. Blog nos anos iniciais do fundamental I: a reconstrução de um clássico infantil. In: ROJO, R. e MOURA, E. Multiletramentos na escola. São Paulo: Parábola Editorial, 2012, p. 35-54.

LOURENÇO FILHO, M. B. Testes ABC- para verificação da maturidade necessária à aprendizagem da leitura e da escrita. São Paulo: Melhoramentos, 1934 (Biblioteca da Educação- v. XX).

MAGALHÃES, I. Letramento, intertextualidade e prática social crítica. In: MAGALHÃES, I. (org.). Discurso e práticas de letramento: pesquisa etnográfica e formação de professor. Mercado de Letras, 2012, p. 17-68.

MARX, K. (1844/2004) Manuscritos econômicos- filosóficos. São Paulo: Martin Claret. MONVELADE, J. Educação pública no Brasil: contos e descontos. Ailandia: Ideia Editores, 1997. 
MORTATTI, M. do R. L. Os sentidos da alfabetização (São Paulo/1876-1994). São Paulo: editora UNESP, 2000.

MORTATTI, M. do R. L. Alfabetização no Brasil: conjecturas sobre as relações entre políticas públicas e seus sujeitos privados. Revista Brasileira de Educação. Vol. 15, num. 44, maio/ago 2010.

PAIVA, J. M. Colonização e catequese. São Paulo: Cortez, 1982.

PENNYCOOK, A. Uma linguística aplicada transgressiva. In: MOITA LOPES, L.P. (org.). Por uma Linguística Aplicada INdisciplinar. São Paulo: Parábola, 2006, pp.6784.

OLIVEIRA, K. R. G. A. de. João de Deus, a Cartilha Maternal e o ensino de leitura em Portugal. História da Educação. ASPHE/FaE/UFPel, Pelotas (4):49-56, set. 98. Disponível em: <file:///C:/Users/User/Downloads/30688-119050-1-PB.pdf>. Acesso em 5 mar. 2014

RAJAGOPALAN, K. Por uma linguística crítica. Revista Línguas e Letras, v.8, n.14, p. 13-20, $\quad 1^{\circ} \quad$ sem. 2007. Disponível em revista.unioeste.br/index.php/linguaseletras/article/download/900/765>>. Acesso em 13 de fevereiro de 2014.

ROJO, R. Letramentos múltiplos, escola e inclusão social. São Paulo: Parábola Editorial, 2009.

ROJO, R. Pedagogia dos multiletramentos: diversidade cultural e de linguagens na escola. In: ROJO, R. e MOURA, E. Multiletramentos na escola. São Paulo: Parábola Editorial, 2012, p. 11-31.

SMOLKA, A. L. B. A criança na fase inicial da escrita. A alfabetização como processo discursivo. 12 ${ }^{\mathrm{a}}$ Ed. Cortez; Campinas, SP: Editora da UNICAMP, 2008.

SOARES, M. Letramento: um tema em três gêneros. 3.ed. Belo Horizonte: Autêntica, 1998/ 2012.

SOARES, M. Letramento e alfabetização: muitas facetas. Revista Brasileira de educação, nº 25, p. 5-17, jan/fev/mar/abr 2004.

STREET, B. V. Social Literacies. Critical Approaches to Literacy in development, ethnography and education. Harlow, Essex: Longman, 1995. 
TEIXEIRA, D. de O. e MOURA, E. Chapeuzinho Vermelho na cibercultura: por uma educação linguística com multiletramentos. In: ROJO, R. e MOURA, E. Multiletramentos na escola. São Paulo: Parábola Editorial, 2012, p. 55-7. 